\title{
Modification of an Engineered Escherichia Coli by a Combinatorial Strategy to Improve 3,4- Dihydroxybutyric Acid Production
}

Yidi Liu

East China University of Science and Technology

Xinlei Mao

East China University of Science and Technology

Baoqi Zhang

East China University of Science and Technology

Jinping Lin ( $\nabla$ jplin@ecust.edu.cn )

East China University of Science and Technology https://orcid.org/0000-0002-6788-1602

Dongzhi Wei

East China University of Science and Technology

\section{Research Article}

Keywords: 3,4-DHBA, D-xylose, competing pathway, fusion expression, E. coli

Posted Date: April 29th, 2021

DOl: https://doi.org/10.21203/rs.3.rs-428690/v1

License: (a) This work is licensed under a Creative Commons Attribution 4.0 International License. Read Full License 


\section{Abstract}

Objectives: 3,4-Dihydroxybutyric acid (3,4-DHBA) is a multi-functional C4 platform compound with wide applications in the synthesis of materials and pharmaceuticals. Currently, although the biosynthetic pathway for the production of 3,4-DHBA has been developed, low productivity still hampers its use on large scales. Here, a non-natural four-steps biosynthetic pathway was established in recombinant $E$. coli with a combinatorial strategy.

Results: Firstly, several aldehyde dehydrogenases (ALDHs) were screened and characterized for catalyzing the dehydrogenation of 3,4-dihydroxybutanal (3,4-DHB) to 3,4-DHBA through in vitro enzyme assays. Secondly, a recombinant $E$. coli was successfully constructed to generate 3,4-DHBA from Dxylose by introducing the pathway containing BsGDH, YagF, PpMdIC and ALDH into E. coli with $3.04 \mathrm{~g} / \mathrm{L}$ 3,4-DHBA obtained. Then, disruption of competing pathways by deleting $x y / A$, ghrA, ghrB and adhP genes contributed to increase the accumulation of 3,4-DHBA by $87 \%$. Final, fusion expression of PpMdIC and YagF resulted in an enhancement of 3,4-DHBA titer $(7.71 \mathrm{~g} / \mathrm{L})$, as the highest titer reported so far.

Conclusions: These results showed that deleting competing pathways and constructing fusion protein could significantly improve the 3,4-DHBA titer in engineered E. coli.

\section{Introduction}

3,4-DHBA is an important C4 compound containing hydroxyl and carboxyl groups which could be modified to produce antibiotics(Choi et al.), $\alpha$ - and $\beta$-amino acids and peptides(Sang et al. 2010). 3HBL, the lactone of 3,4-DHBA, was also a multi-functional chiral building block for various chiral drugs including antilipemic agent atorvastatin(Brower et al.) (the active ingredients of Lipitor of Pfizer), neurotransmitter L-carnitine(Tetrahedron 1990), HIV proteases inhibitor Amprenavir(Kim E E 1995), dermatological medicine 12-HETE(Corey E J 1978), anti-cancer drug aplysistatin(Shieh H M 1982).

Nowadays, 3,4-DHBA has been mainly produced by chemical processes through the reaction between glucose and alkali metal hydroxides, which is catalyzed by $\mathrm{H}_{2} \mathrm{O}_{2}$ at $70^{\circ} \mathrm{C}$ for 24 hours(Hollingsworth 1994), or the reaction of hydrocyanation and hydrolyzation from $R$-3-chloro-1,2-propanediol(Inoue et al. 1991). However, these approaches were usually with low yield, harsh reaction conditions, complex purification process of product, high costs as well as environmental pollution. In order to avoid these kinds of problems, efforts have been made to produce 3,4-DHBA by microbial fermentation. Therefore, considerable attentions were attracted by the biosynthesis of 3,4-DHBA from renewable sources.

There is no report on the natural pathway for producing 3,4-DHBA. The first de novo biosynthesis of 3,4DHBA involved with six-step enzymatic reaction using glucose and donors of acyl-CoA as a substrate was developed in E. coli(Liu et al. ; Schweiger and Buckel ; Taguchi et al. 2008). After optimizations by Dhamankar et al, $0.7 \mathrm{~g} / \mathrm{L}$ 3,4-DHBA was achieved(Himanshu et al.). However, too many reaction steps, low catalytic efficiency and yield made it inaccessible to apply to industrial production. 
D-xylose has a high proportion in lignocellulose, which is as the most abundant renewable energy in nature(Choi et al. ; Kawaguchi et al. 2016). A novel five-step biosynthetic pathway for generating 3,4DHBA from D-xylose was constructed in E. coli(Wang et al.). In this route, xylose is catalyzed to 3,4-DHBA by dehydrogenations twice, oxidization, dehydration and decarboxylation. In shake flask experiments, the titer of 3,4-DHBA achieved $1.27 \mathrm{~g} / \mathrm{L}$, while $0.18 \mathrm{~g} / \mathrm{L}$ of by-product 1,2,4-butanetriol (BTO) was also obtained. However, this titer was still low for lacking of high-activity enzymes to decarboxylating 2-keto-3deoxy-D-xylonate and dehydrogenating 3,4-DHB efficiently, and intermediate products were consumed by competing pathways.

Here, a four-steps biosynthetic pathway using D-xylose as a precursor to produce 3,4-DHBA (Fig. 1) was built. Several aldehyde dehydrogenases (ALDHs) were screened and characterized for 3,4-DHBA accumulation. Secondly, the competing pathways were disrupted by deleting $x y / A$, ghrA, ghrB and adhP genes. Finally, a fusion construct containing PpMdIC and YagF was created to improve 3,4-DHBA titer. This work lays some strategies for achieving high 3,4-DHBA titer accumulation.

\section{Methods And Materials}

\section{Strains, plasmids and culture conditions}

The E. coli BL21(DE3) was used for expressing, purifying target proteins and producing 3,4-DHBA. Strains used in this study were showed in Table 1. The plasmids of pET28a and pACYC184 were used for cloning and expressing the target genes. E. coli cells were cultured at $37^{\circ} \mathrm{C}$ in Luria-Bertani medium added with appropriate concentration antibiotics. And plasmids in this study were showed in Table S1.

Table 1 E. coli strains used in this study 


\begin{tabular}{|c|c|c|}
\hline Strains & Description & Source \\
\hline $\begin{array}{l}\text { E. coli } \\
\text { BL21(DE3) }\end{array}$ & Expression, purification and production & $\begin{array}{l}\text { Our } \\
\text { laboratory }\end{array}$ \\
\hline E-C4-01 & $\begin{array}{l}\text { E. coli BL21(DE3) carrying pE01 (pET28a harboring E. coli yagF and } P \text {. } \\
\text { putida PpmdlC) and pA01 (pACYC184 harboring E. coli yneland } B . \\
\text { subtilis gdh) }\end{array}$ & $\begin{array}{l}\text { This } \\
\text { study }\end{array}$ \\
\hline E-C4-02 & $\begin{array}{l}\text { E. coli BL21(DE3) carrying pE01 and pA02 (pACYC184 harboring } G \text {. } \\
\text { oxydans gox0499 and B. subtilis gdh) }\end{array}$ & $\begin{array}{l}\text { This } \\
\text { study }\end{array}$ \\
\hline E-C4-03 & $\begin{array}{l}\text { E. coli BL21(DE3) carrying pE01 and pA03 (pACYC184 harboring } G \text {. } \\
\text { oxydans gox } 1122 \text { and B. subtilis gdh) }\end{array}$ & $\begin{array}{l}\text { This } \\
\text { study }\end{array}$ \\
\hline E-01-C4 & E. coli BL21(DE3) $\triangle x y / A$ carrying $\mathrm{pE} 01$ and pA02 & $\begin{array}{l}\text { This } \\
\text { study }\end{array}$ \\
\hline $\mathrm{E}-02-\mathrm{C} 4$ & E. coli BL21(DE3) $\Delta x y / A \Delta g h r A$ carrying $\mathrm{pE} 01$ and $\mathrm{pA} 02$ & $\begin{array}{l}\text { This } \\
\text { study }\end{array}$ \\
\hline E-03-C4 & E. coli BL21(DE3) $\triangle x y l A \Delta g h r A$ carrying $\mathrm{pE} 01$ and pA02 & $\begin{array}{l}\text { This } \\
\text { study }\end{array}$ \\
\hline $\mathrm{E}-04-\mathrm{C} 4$ & E. coli BL21(DE3) $\triangle x y l A \Delta g h r A \Delta g h r B$ carrying pE01 and pA02 & $\begin{array}{l}\text { This } \\
\text { study }\end{array}$ \\
\hline E-05-C4 & E. coli BL21(DE3) $\Delta x y l A \Delta g h r A \Delta g h r B \Delta a d h P$ carrying pE01 and pA02 & $\begin{array}{l}\text { This } \\
\text { study }\end{array}$ \\
\hline E-05-F4 & $\begin{array}{l}\text { E. coli BL21(DE3) } \triangle x y / A \Delta g h r A \Delta g h r B \Delta a d h P \text { carrying pE02 (pET28a } \\
\text { harboring fusion gene of E. coli yagF and } P \text {. putida PpmdlC) and pA02 }\end{array}$ & $\begin{array}{l}\text { This } \\
\text { study }\end{array}$ \\
\hline
\end{tabular}

\section{Construction of plasmids}

The primers sequences used are listed in Table S2. pE01 harboring yag $F$ from E. coli and PpmdIC from $P$. putida was constructed. The genes of yagF and PpmdIC were fusion expressed by cloning and inserting the gene of linker peptide $E R / K$ a-helix(Sivaramakrishnan and Spudich 2011) to create a fusion construct. Similarity, pE04, pE05 and pE06 carrying gdh from B. subtilis and different ALDH genes, respectively.

\section{The disruption of competing pathways}

The disruption of competing pathway was accomplished by CRISPR-Cas9. The donor DNA was connected by overlapping PCR from 500 bp upstream and downstream homologous arm. The E. coli BL21(DE3) carrying pCas vector was inoculated in $30^{\circ} \mathrm{C}$ and then added into $10 \mathrm{mM}$ arabinose for inducing the expression of Cas 9 . When $\mathrm{OD}_{600}$ reached $0.5-0.6$, the $E$. coli cells were arranged on ice for 30 min. After washed by $10 \%$ glycerol sterile three times, it was split into $100 \mu \mathrm{L}$ per tube. The competent cells carrying pCas were mixed with $100 \mathrm{ng}$ pTargetT vector and $400 \mathrm{ng}$ donor DNA to have an electrotransformation $(2.5 \mathrm{kV}, 200 \Omega, 25 \mu \mathrm{F})$ with an electrical shock time within $5 \mathrm{~ms}$. Then they were cultivated into $30^{\circ} \mathrm{C}$ and confirmed by colony PCR. 
E. coli cells were cultured in $30^{\circ} \mathrm{C}$ with addition of $0.5 \mathrm{mM}$ IPTG overnight to eliminate pTargetT series because IPTG could induce the other sgRNA, which targets one PAM site of pTargetT. The pCas vector could be cured by cultivating it in $37^{\circ} \mathrm{C}$ to remove because its temperature sensitivity.

\section{Protein expression and purification}

E. coli cells were cultured at $37^{\circ} \mathrm{C}$ until the $\mathrm{OD}_{600}$ was approximately $0.6-0.8$, and then $0.2 \mathrm{mM} \mathrm{IPTG}$ was used to induce target proteins expression at $20^{\circ} \mathrm{C}$ for $16 \mathrm{~h}$. Then the cells were collected by centrifugated at $8000 \mathrm{rpm}$ for $10 \mathrm{~min}$, washed by $0.9 \% \mathrm{NaCl}$ twice and resuspended in appropriate volume PB solution at pH $7.5\left(20 \mathrm{mM} \mathrm{Na}_{2} \mathrm{HPO}_{4}\right.$ and $\left.\mathrm{NaH}_{2} \mathrm{PO}_{4}\right)$. The resuspended cells were centrifuged to collect the supernatants for purification after ultrasonication. The supernatants were filtered, loaded in the preequilibrated ( $20 \mathrm{mM}$ imidazole, $\mathrm{pH}$ 7.5) Ni-chelating column with and then washed with different concentration of imidazole ( $20 \mathrm{mM}$ and $50 \mathrm{mM}, \mathrm{pH} 7.5)$. The bound proteins would be eluted by $250 \mathrm{mM}$ imidazole ( $\mathrm{pH}$ 7.5). The protein samples were then put into dialysate $(20 \mathrm{M}$ PB solution, $200 \mathrm{mM} \mathrm{NaCl}$ and $5 \%$ glycerol, $\mathrm{pH} 7.5$ ) overnight, and then identified by $12 \%$ SDS-PAGE.

\section{Enzymes activity assay}

The in vitro enzyme assay of YagF and PpMdIC under tandem expression and fusion expression was implemented in $50 \mathrm{mM}$ PB solution at pH 7.5 which contains $20 \mathrm{mM}$ D-xylonate, $10 \mathrm{mM} \mathrm{MgCl} 2,1 \mathrm{mM}$ TPP, $1 \mathrm{mM} \mathrm{NAD}{ }^{+}$. The reaction was incubated at $30^{\circ} \mathrm{C}$ for $5 \mathrm{~min}$ to allow accumulation of 3,4-DHB produced by 5-fold excess of YagF, PpMdIC or 5-fold fusion protein of YagF and PpMdIC. The enzyme assay was monitored for the production of NADH at $340 \mathrm{~nm}$ after $1 \mathrm{mM}$ aldehyde dehydrogenase Ynel was supplied to the reaction.

The in vitro enzyme assay of $\mathrm{NAD}^{+}$-dependent aldehyde dehydrogenase activity of Ynel, Gox0499 and Gox1122 was tested in $50 \mathrm{mM}$ PB solution at pH 7.5 and contained $20 \mathrm{mM} \mathrm{D}$-xylonate, $10 \mathrm{mM} \mathrm{MgCl}_{2}, 1$ $\mathrm{mM}$ TPP, $1 \mathrm{mM} \mathrm{NAD}{ }^{+}, 5$-fold excess of YagF and PpMdlC. The reaction was incubated at $30^{\circ} \mathrm{C}$ for $5 \mathrm{~min}$ to allow accumulation of 3,4-DHB before supplying $1 \mathrm{mM}$ aldehyde dehydrogenase of Ynel, Gox0499 and Gox1122 to the reaction, respectively. This reaction was also monitored for the production of NADH at $340 \mathrm{~nm}$, too.

\section{Whole-cell catalysis for 3,4-DHBA production}

Whole-cell catalysis was performed in $20 \mathrm{~mL}$ scale, containing $20 \mathrm{~g} / \mathrm{L}$ of D-xylose, $50 \mathrm{mM}$ PB solution (pH 7.5), $50 \mathrm{~g} / \mathrm{L}$ of $E$. coli cells, $2 \mathrm{mM} \mathrm{TPP}, 2 \mathrm{mM} \mathrm{NAD}+, 10 \mathrm{mM} \mathrm{Mg}^{2+}$ at $30^{\circ} \mathrm{C}$. The products were sampled about $1 \mathrm{~mL}$ in every $12 \mathrm{~h}$ and analyzed via HPLC.

\section{Analytical methods}

Metabolite analysis was performed by HPLC on a Transgenomic $87 \mathrm{H} 3$ column, using refractive-index detection (RID). The mobile phase was $0.08 \mathrm{~N} \mathrm{H}_{2} \mathrm{SO}_{4}$ with a flow rate of $0.38 \mathrm{~mL} / \mathrm{min}$. The temperatures 
of the RID detector and column were $35^{\circ} \mathrm{C}$. HPLC-MS was used to distinguishing 3,4-DHBA from the supernatants of reaction (Fig. S1). 3,4-DHBA $\left(\mathrm{C}_{4} \mathrm{H}_{8} \mathrm{O}_{4}\right)$ was corresponded to the peak of $119.03 \mathrm{Da}$ under the negative ion mode.

\section{Results And Discussion}

\section{Selection of enzymes for the dehydrogenation of 3,4-dihydroxybutanal}

The biosynthetic pathway of 3,4-DHBA through D-xylose comprises four steps. Firstly, BsGDH from $B$. subtilis was showed capable of catalyzing D-xylose to produce D-xylonate(Li et al.). Then, it is reported that YagF from E. coli and PpMdIC from P. putida was able to convert D-xylonate to 2-keto-3-deoxy-Dxylonate and produce 3,4-dihydroxybutanal (3,4-DHB) from 2-keto-3-deoxy-D-xylonate, respectively (Synthetic pathway optimization for improved 1,2,4-butanetriol production 2016).

Finally, Ynel from E. coli was demonstrated to convert 3.4-DHB to 3,4-DHBA(Wang et al. 2017). However, Ynel generates 3,4-DHBA as well as BTO as a byproduct. In order to obtain high active oxidase to minimize the production of BTO, we found two NAD+-dependent aldehyde dehydrogenases (Gox0499 and Gox1122) from G. oxydans and compared the catalytic activity with Ynel in vitro enzyme assays. The enzymatic assays of aldehyde dehydrogenases were implemented on cell lysate to calculate the approximate enzymatic activity. Gox0499 has a highest specific activity of $4.26 \mathrm{U} / \mathrm{mg}$ protein compared with Ynel $(2.67 \mathrm{U} / \mathrm{mg}$ protein $)$ and Gox1122 (2 U/mg protein).

To evaluate their catalytic activity in vivo, plasmids of pE01 (carrying yagF and PpmdIC), pA01 (carrying ynel and gdh), pA02 (carrying gox0499 and gdh), pA03 (carrying gox1122 and gdh) were constructed to assemble the whole 3,4-DHBA biosynthetic pathway in E. coli BL21(DE3). The SDS-PAGE of target proteins of recombinant strain E-C4-01, E-C4-02 and E-C4-03 was showed in Fig. 2A after cultivating and target inducing. BsGDH, YagF and PpMdIC have same expression quantity in three respective strains, but ALDHs were different. Gox1122 was higher than Ynel and Gox0499.

Then, strains E-C4-01, E-C4-02 and E-C4-03 were used for the whole-cell catalysis for 3,4-DHBA production. As seen from Fig. 2B, strain E-C4-02 produced approximately $3.04 \mathrm{~g} / \mathrm{L} 3,4-\mathrm{DHBA}$ after $60 \mathrm{~h}$ whole-cell catalytic process with $0.56 \mathrm{~g} / \mathrm{L}$ byproduct BTO. Compared with E-C4-01 and E-C4-03, E-C4-02 has the highest titer of 3,4-DHBA and the lowest titer of BTO. Since Gox0499 was shown to be the most efficient enzyme for dehydrogenation of 3,4-DHB under a lower protein expression, it was selected for producing 3,4-DHBA.

\section{Disruptions of the competing pathway to improve 3,4-DHBA titer}

In order to improve 3,4-DHBA titer from D-xylose, several competing pathways of $E$. coli was deleted by CRISPR/Cas 9. The xylose isomerase encoded by the $x y / A$ catalyzes the production of D-xylulose from Dxylose, flowing to the pentose phosphate pathway for bacteria's growth and metabolism. 2-keto-3-deoxy$\mathrm{d}$-xylonate aldolases, expressed by yagE and $y j h G$ of Dahms pathway, always consumed intermediate 
product 2-keto-3-deoxy-d-xylonate in E. coli(Valdehuesa et al. 2014). However, there are no yagE and yjhG genes of Dahms pathway but two genes of $g h r A$ and $g h r B$ which encode glyoxylate reductases play the same roles in E. coli BL21(DE3). Besides, alcohol dehydrogenase encoded by adhP has a strong reduction activity, which has high preference for producing byproduct BTO from 3,4-DHB(Wang et al. 2017).

After knocking these competing genes out, $x y / A$-deficient strain E-01-C4, $x y / A$ and $g h r A$ genes doubledeficient strain E-02-C4, $x y / A$ and ghrB genes double-deficient strain E-03-C4, $x y / A$, ghrA and ghrB genes triple-deficient strain E-04-C4, and $x y / A, g h r A, g h r B$ and $a d h P$ quadruple-deficient genes strain E-05-C4 were constructed by CRISPR Cas9, respectively. There is no significant difference of expression of target proteins between these engineered strains (Fig. S2). It means that the deletion of $x y / A, g h r A, g h r B$ and $a d h P$ has showed no effects on the expression of the target proteins in the host cell.

E-01-C4 has a 56\% higher of titer of 3,4-DHBA than E-C4-02 (Fig. 3). It shows that the deletion of $x y / A$ gene could minimize the byproduct formation of $D$-xylulose and increase the $D$-xylose flux toward $D$ xylonate. The titer of 3,4-DHBA produced by E-02-C4, E-03-C4 and E-04-C4 was 5.05, 5.24 and $5.38 \mathrm{~g} / \mathrm{L}$, respectively. This result indicates that the knockout of ghrA and ghrB has increased the titer of 3,4-DHBA but not obvious. $5.69 \mathrm{~g} / \mathrm{L}$ 3,4-DHBA was produced by $x y / A$, ghrA, ghrB and adhP quadruple-deficient genes strain E-05-C4, and the titer of BTO was decreased $0.56 \mathrm{~g} / \mathrm{L}$ to $0.33 \mathrm{~g} / \mathrm{L}$, proving that the disruption of adhP was essential for producing 3,4-DHBA. Above all, E-05-C4 had the highest yield, achieving an average of $5.69 \mathrm{~g} / \mathrm{L}$, an $87 \%$-fold improvement on production from E-C4-02. And the disruption of these competing pathway could increase the yield of 3,4-DHBA indeed.

\section{Fusion expression of $P p M d I C$ and YagF to strengthen carbon flux to 3 ,4-DHBA pathway}

PpMdIC was the rate-limited enzyme in this pathway because of lower catalytic activity (Wang et al. 2017; Weiqun et al. 2019), which causing the accumulation of intermediate products and consumption of competing pathway. Multifunctional enzymes could be constructed through the co-expression of fusion proteins(Chen et al. 2016). It is shown that enhancing the spatial proximity of enzymes by constructing fusion proteins can increase catalytic efficiency and the titer of product in multi-enzyme cascade reaction by previous studies (Albertsen et al. 2011; Lu et al. 2006; Ryosuke et al. 2018). Here, a fusion construct containing PpMdlC and YagF with a 5-nm rigid a-helical ER/K motif was created, and the obtained recombinant plasmid $\mathrm{pE} 02$ was co-transformed into $E$. coli $\mathrm{BL}(\mathrm{DE} 3)$ with $\mathrm{pA02}$, generating the engineered strain E-05-F4.

Compared with the engineered stain E-05-C4 harboring plasmid pE01 and pA02, the protein expressions of PpMdIC and YagF of E-05-F4 were lower than E-05-C4 (Fig. 4A). Meanwhile, there is a new protein showed over $120 \mathrm{kDa}$, which means that fusion protein containing PpMdlC and YagF was constructed successfully. The catalytic activity of PpMdIC and YagF under tandem and fusion expression was compared by monitoring the change of NADH absorbance at $340 \mathrm{~nm}$ with D-xylonate as a substrate and 
cascading Gox0499. And the catalytic activity of fusion protein containing PpMdlC and YagF was only $1.09 \mathrm{U} / \mathrm{g}$ wet cell compared to $2.53 \mathrm{U} / \mathrm{g}$ wet cell of PpMdlC and YagF under tandem expression.

Further comparison of 3,4-DHBA titer was performed between the engineered strains E-05-C4 and E-05-C4. The consumption rate of the substrate $D$-xylose of these two engineered strains is similar (Fig. 4B). And the 3,4-DHBA titer of E-05-F4 accumulated was always higher and the reaction ended 12 hours earlier than E-05-C4. Compared to the engineered strain E-05-C4, E-05-F4 exhibited higher 3,4-DHBA titer and productivity at decreased enzymatic activity of PpMdIC and YagF. The close spatial proximity of $P p M d I C$ and YagF might prevent the diffusion of the intermediate 2-keto-3-deoxy-D-xylonate and effectively regulated catalytic efficiency by constructing variants by fusion enzyme.

\section{Conclusion}

In this study, we developed a four-step enzymatic reaction pathway in E. coli for producing 3,4-DHBA from D-xylose efficiently. Apart from YagF from E. coli and PpMdIC from P. putida in the 3,4-DHBA biosynthetic pathway reported before(Valdehuesa et al. 2014), BsGDH from $B$. subtilis was selected to catalyze the reaction from $D$-xylose to $D$-xylonate in our route. Besides, aldehyde dehydrogenase Gox0499 from $G$. oxydans which exhibited higher activity than Ynel from E. coli: ${ }^{[21]}$ was chosen to catalyze 3,4-DHB to 3,4DHBA, resulting in higher 3,4-DHBA titer and lower byproduct BTO titer. Then, the recombinant $E$. coli was modified by a combined strategy of deleting competing pathway, as well as fusion expression of $P p M d I C$ and YagF. The whole cells of the obtained strain E-05-F4 could produce $7.71 \mathrm{~g} / \mathrm{L} \mathrm{3,4-DHBA}$ at productivity rate of $3.864 \mathrm{~g} /\left(L^{\star} \mathrm{d}\right)$, as the highest titer reported so far.

\section{Declarations}

\section{Acknowledgments}

This work was supported by the Natural Science Foundation of Shanghai (No. 19ZR1412700), the Fundamental Research Funds for the Central Universities (No. 22221818014), and partially supported by the Open Funding Project of the State Key Laboratory of Bioreactor Engineering.

\section{References}

1. Albertsen L et al (2011) Diversion of Flux toward Sesquiterpene Production in Saccharomyces cerevisiae by Fusion of Host and Heterologous Enzymes. Appl Environ Microbiol 77:1033-1040

2. Brower PL, Butler DE, Deering CF, Le TV, Millar A, Nanninga TN, Letters BDRJT (1992) The synthesis of (4R-cis)-1,1-dimethylethyl 6-cyanomethyl-2,2-dimethyl-1,3-dioxane-4-acetate, a key intermediate for the preparation of $\mathrm{Cl}-981$, a highly potent, tissue selective inhibitor of HMG-CoA reductase. Tetrahedron Lett 33:2279-2282

3. Chen K, Li K, Deng J, Zhang B, Lin J, Wei D (2016) Carbonyl reductase identification and development of whole-cell biotransformation for highly efficient synthesis of $(R)$-[3,5- 
bis(trifluoromethyl)phenyl] ethanol. Microb Cell Fact 15:191

4. Choi KY, Wernick DG, Tat CA et al (2014) Consolidated conversion of protein waste into biofuels and ammonia using Bacillus subtilis. Metab Eng 23:53-61

5. Choi S, Song CW, Shin JH et al (2015) Biorefineries for the production of top building block chemicals and their derivatives. Metab Eng 28:223-239

6. Corey EJNH, Knolle J (1978) Total sythesis of (S)-12-hydroxy-5,8,14-cis,-10-trans-eicosatetraenoic acid (Samuelesson's HETE). J Am Chem Soc 100(6):1942-1944

7. Himanshu et al (2014) Engineering E. coli for the biosynthesis of 3-hydroxy-y-butyrolactone (3HBL) and 3,4-dihydroxybutyric acid (3,4-DHBA) as value-added chemicals from glucose as a sole carbon source. Metab Eng 25:72-81

8. Hollingsworth RI (1994) Process For The Preparation Of 3,4-Dihyd Roxybutanoic Acid And Salts Thereof. US Patent US5374773 A

9. Inoue K, Matsumoto M, Takahashi S (1991) Method for preparing optically active 3,4-dihydroxy butyric acid derivatives. US Patent US4994597 A

10. Kawaguchi H, Hasunuma T, Ogino C, Kondo A (2016) Bioprocessing of bio-based chemicals produced from lignocellulosic feedstocks. Curr Opin Biotechnol 42:30-39

11. Kim EE, Dwyer BCT M D, et al (1995) Crystal structure of HIV-1 protease in complex with VX-478, a potent and orally bioavailable inhibitor of the enzyme. J Am Chem Soc 117(3):1181-1182

12. Li J et al (2017) Ala258Phe substitution in Bacillus sp. YX-1 glucose dehydrogenase improves its substrate preference for xylose. Process Biochem 56:124-131

13. Liu XW, Wang H-H, Chen J-Y, et, al (2009) Journal G-QCJBE Biosynthesis of poly(3-hydroxybutyrateco-3-hydroxyvalerate) by recombinant Escherichia coli harboring propionyl-CoA synthase gene (prpE) or propionate permease gene (prpP). Biochem Eng J 43:72-77

14. Lu P, Feng MG, Li WF, Hu CX (2006) Construction and characterization of a bifunctional fusion enzyme of Bacillus-sourced beta-glucanase and xylanase expressed in Escherichia coli. Fems Microbiology Letters 261:224-230

15. Ryosuke et al (2018) Muconic Acid Production Using Gene-Level Fusion Proteins in Escherichia coli. ACS Synth Biol 7:11:2698-2705

16. Sang HP, Lee SH, Sang YL (2010) Preparation of optically active $\beta$-amino acids from microbial polyester polyhydroxyalkanoates. Journal of Chemical Research 2001:498-499

17. Schweiger G, Buckel W (1984) On the dehydration of (R)-lactate in the fermentation of alanine to propionate by Clostridium propionicum. Febs Letters 171:0-84

18. Shieh HM, PGD (1982) Chiral, biomimetic total synthesis of(-)-aplysistatin. Tetrahedron Lett 23(45):4643-4646

19. Sivaramakrishnan S, Spudich JA (2011) Systematic control of protein interaction using a modular ER/K a-helix linker. Proc Natl Acad Sci USA 108(51):20467-20472 
20. Lei S, Fan, et al (2016) Synthetic pathway optimization for improved 1,2,4-butanetriol production. Journal of Industrial Microbiology Biotechnology 43:67-78

21. Taguchi S, Yamada M, Matsumoto Kl, et, al (2008) A microbial factory for lactate-based polyesters using a lactate-polymerizing enzyme. Proceedings of the National Academy of Sciences 105:1732317327

22. Tetrahedron M (1990) Enantiomerically pure $\beta, \gamma$-epoxyesters from $\beta$-hydroxylactones: synthesis of $\beta$ hydroxyesters and (-)-GABOB. Tetrahedron 46:4277-4282

23. Valdehuesa KNG, Liu H, Ramos K, Si JP, Nisola GM, Lee WK, Chung WJ (2014) Direct bioconversion of $d$-xylose to 1,2,4-butanetriol in an engineered Escherichia coli. Process Biochem 49:25-32

24. Wang J, Shen X, Jain R, Wang J, Yuan Q, Yan Y (2017) Establishing a novel biosynthetic pathway for the production of 3,4-dihydroxybutyric acid from xylose in Escherichia coli. Metab Eng 41:39-45

25. Wang J, Shen X, Jain R, Wang J, Yuan Q, Yan YJME (2017) Establishing a novel biosynthetic pathway for the production of 3,4-dihydroxybutyric acid from xylose in Escherichia coli. Metab Eng 41:39-45

26. Weiqun et al (2019) Metabolic Engineering of a Homoserine-Derived Non-Natural Pathway for the De Novo Production of 1,3-Propanediol from Glucose. ACS Synth Biol 8:587-595

\section{Figures}

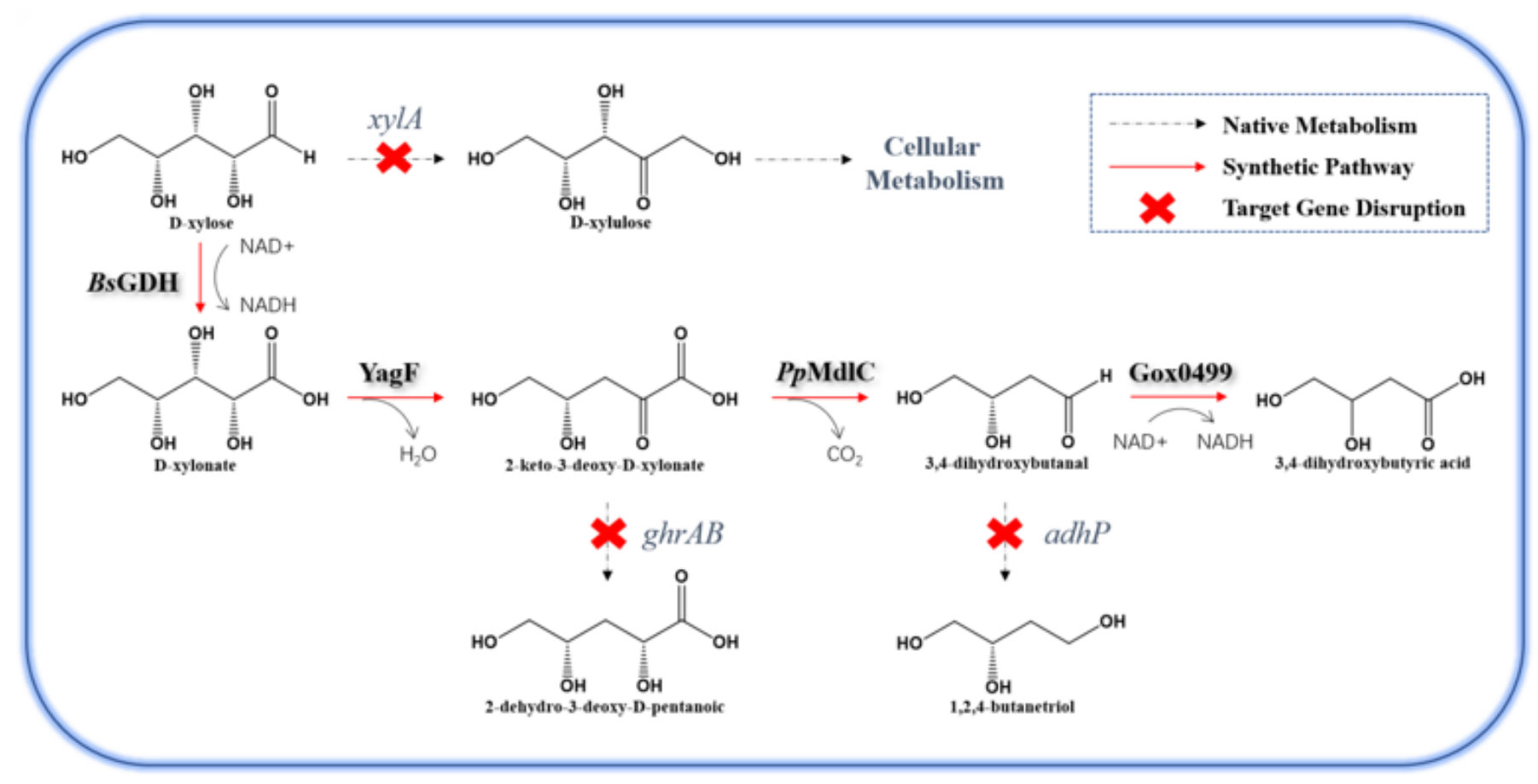

Figure 1 
The pathway from xylose to produce 3,4-DHBA in E. coli. Enzymes: BsGDH: glucose dehydrogenase; YagF: D-xylonate dehydratase; PpMdIC: decarboxylase; ALDH: aldehyde dehydrogenase. Genes: xylA encoding xylose isomerase; ghrA, ghrB encoding glyoxylate reductases, respectively; adhP encoding ethanol dehydrogenase.

Fig. 2A

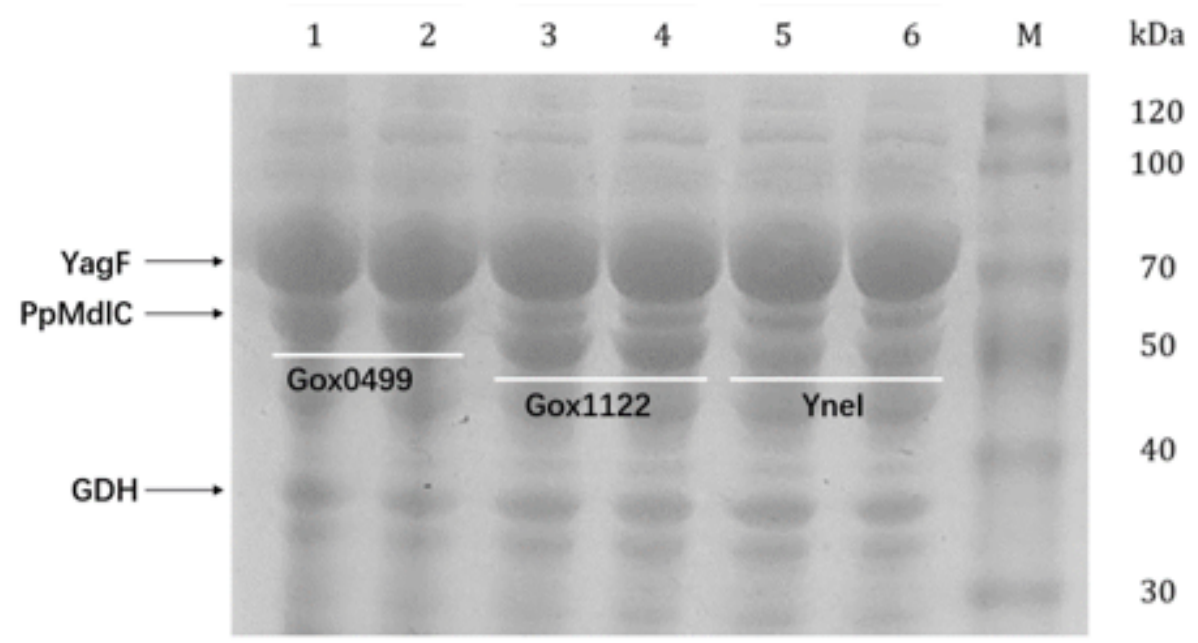

Fig. 2B

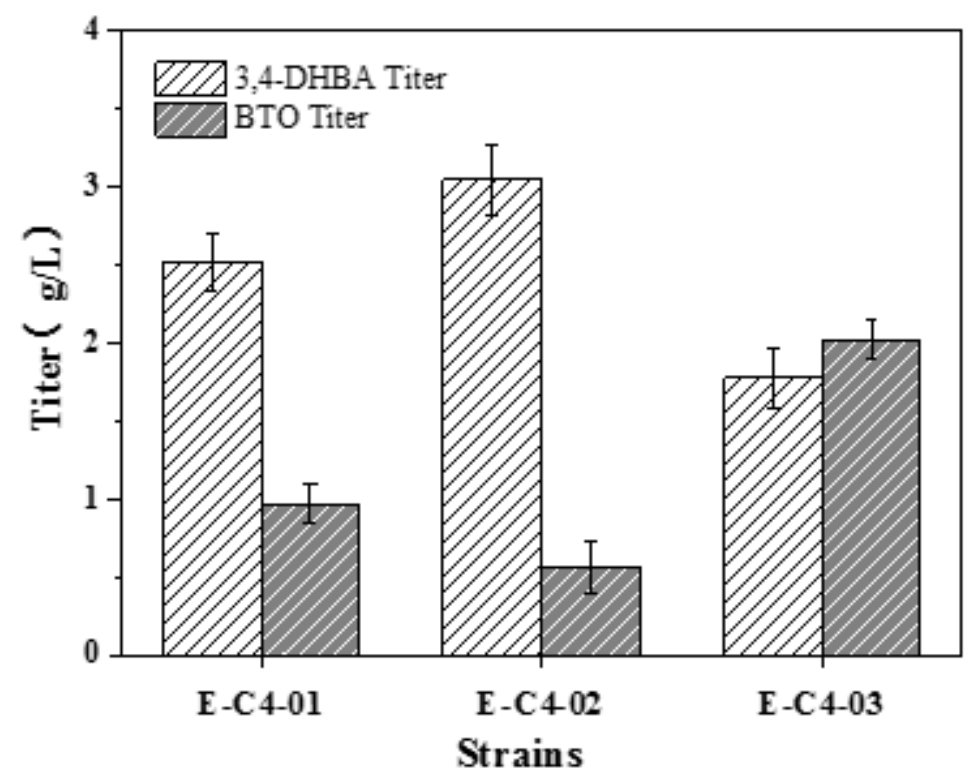

Figure 2

Selection of ALDHs for 3,4-DHBA production. (A)SDS-PAGE analysis of E-C4-01, E-C4-02 and E-C4-03. Lane 1: whole cell of E-C4-02; Lane 2: crude extract of E. coli E-C4-02; Lane 3: whole cell of E-C4-03; Lane 
4: crude extract of E-C4-03; Lane 5: whole cell of E-C4-01; Lane 6: crude extract of E-C4-01; M: protein molecular weight marker. (B)Several strains were constructed to compare the yield of 3,4-DHBA. The highest 3,4-DHBA yield (3.04 g/L) was produced by E-C4-02 containing BsGDH, YagF, PpMdIC and Gox0499.

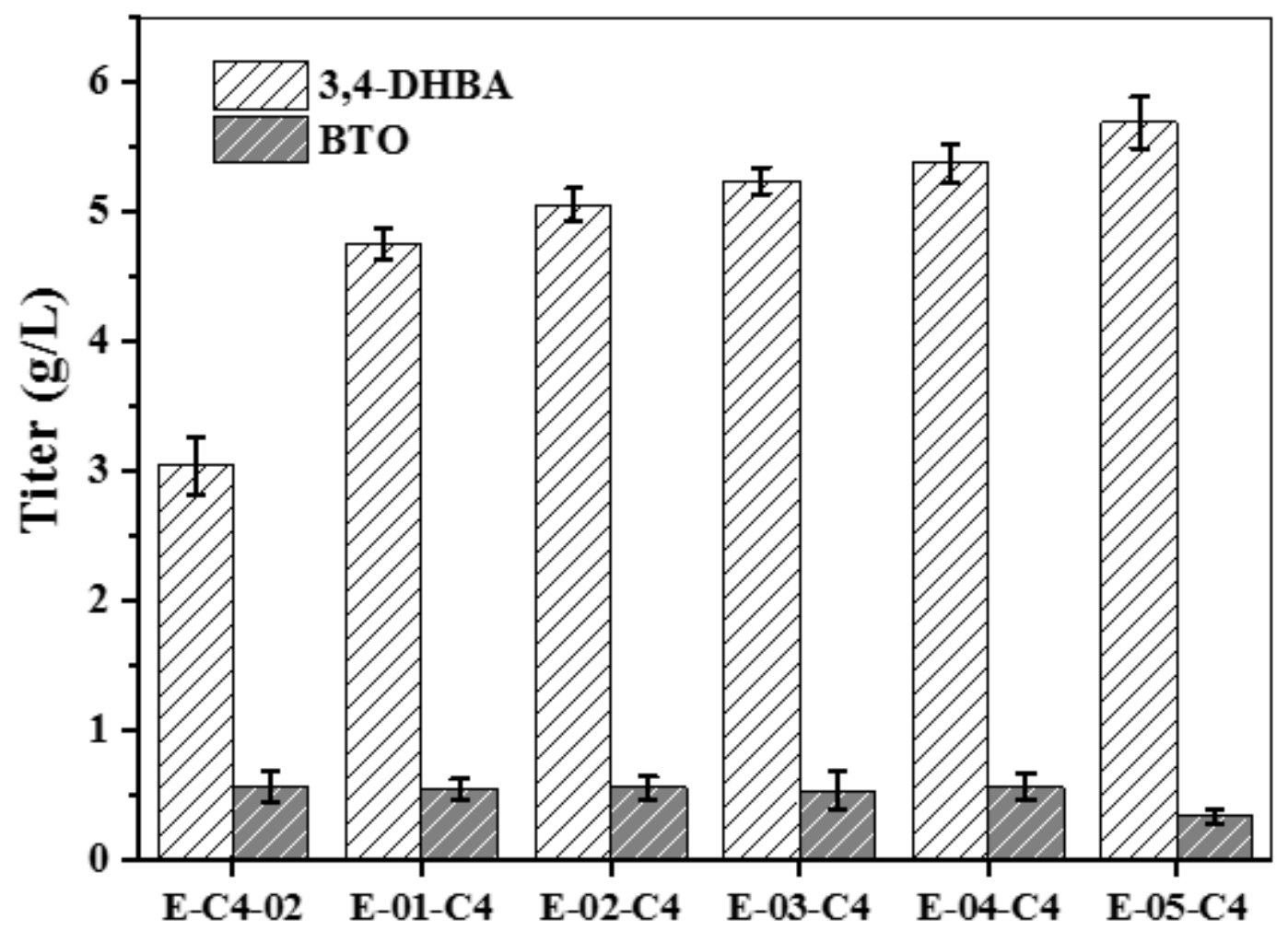

\section{Figure 3}

Disruptions of $x y l A$, ghrA, ghrB and adhP genes for improving 3,4-DHBA production. Production of 3,4DHBA by different engineered strains. 
Fig. 4A

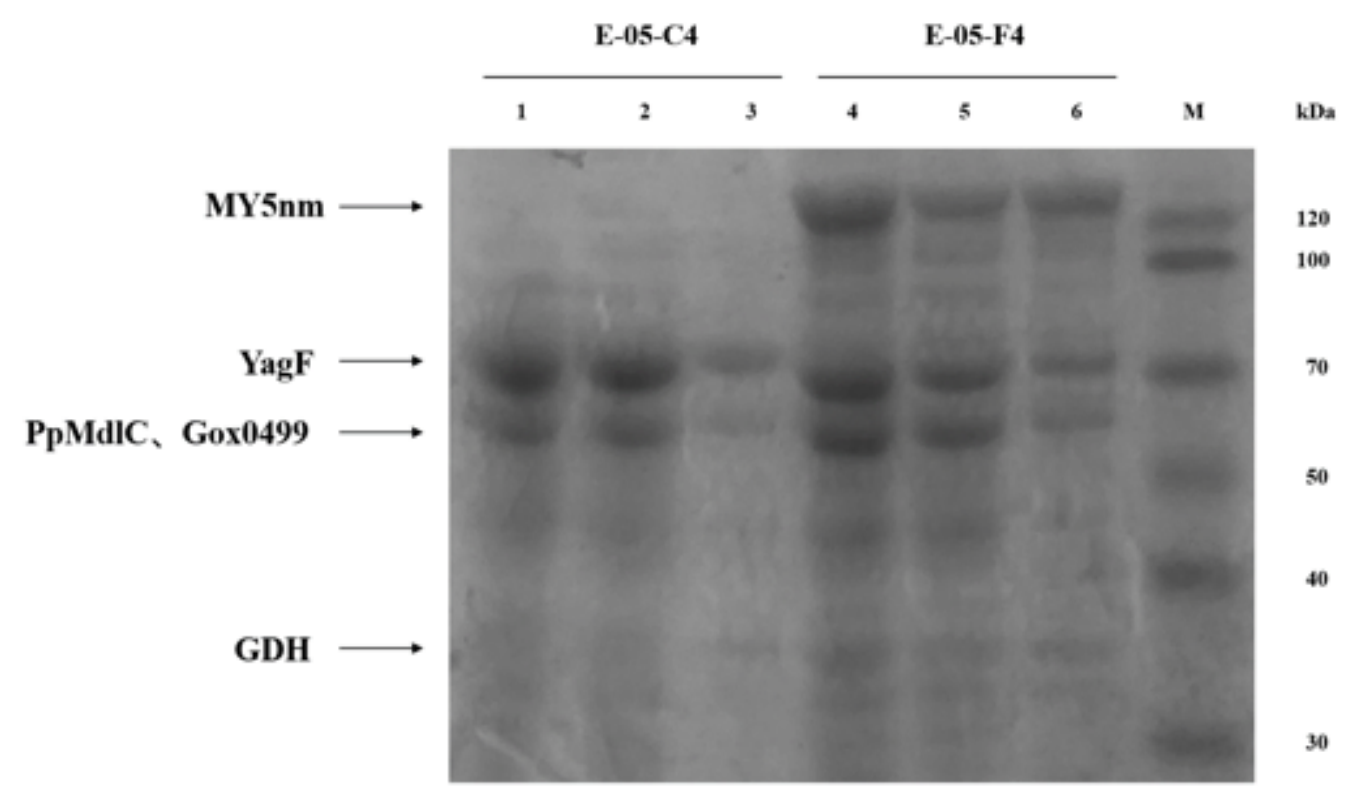

Fig. 4B

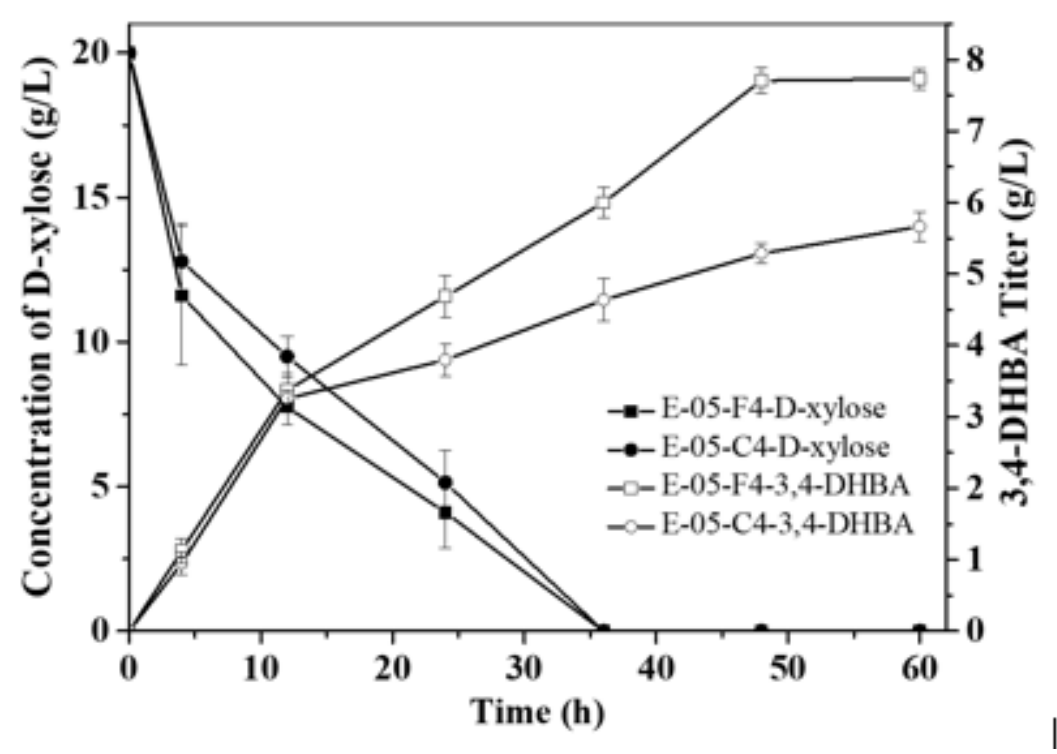

Figure 4

Protein fusion of PpMdIC and YagF to improve 3,4-DHBA production. (A)The SDS-PAGE analysis of E-05C4 and E-05-F4. Lane 1: whole cell of E-05-C4; Lane 2: crude extract of E-05-C4; Lane 3: precipitate of E05-C4; Lane 4: whole cell of E-05-F4; Lane 5: crude extract of E-05-F4; Lane 6: precipitate of E-05-F4; M: protein molecular weight marker. (B)E-05-F4 was engineered to have PpMdIC and YagF fusion expression to enhance the reaction efficiency. The highest 3,4-DHBA titer was $7.71 \mathrm{~g} / \mathrm{L}$ produced by E-05-F4. 


\section{Supplementary Files}

This is a list of supplementary files associated with this preprint. Click to download.

- SupplementarylnformationBLLYD.docx 